\title{
Does inflammation play a role in development of necrobiosis lipoidica?
}

\section{Czy proces zapalny odgrywa rolę w patogenezie obumierania tłuszczowatego?}

Iwona Słowik-Kwiatkowska', Aleksandra Lesiak², Anna Woźniacka², Anna Sysa-Jędrzejowska', Joanna Narbutt'

'Oddział Chorób Wewnętrznych, Endokrynologii i Diabetologii, Wojewódzki Szpital Specjalistyczny im. Stefana Kardynała Wyszyńskiego SPZOZ, Lublin, Poland

2Department of Dermatology and Venereology, Medical University of Lodz, Lodz, Poland

Przegl Dermatol 2014, 101, |87-191

DOI: $\mid 0.5$ | |4/dr.20|4.43808

KEY WORDS:

necrobiosis lipoidica, TNF- $\alpha$, angiogenesis, inflammation.

SŁOWA KLUCZOWE:

obumieranie tłuszczowate, TNF- $\alpha$ angiogeneza, zapalenie.
ADDRESS FOR CORRESPONDENCE:

Prof. Joanna Narbutt MD, PhD

Department of Dermatology

Medical University of Lodz

pl. Hallera 1, 90-647 Łódź, Poland

Phone/fax: +48 4268679 81/

+48426884565

E-mail:

joanna.narbutt@umed.lodz.pl

\begin{abstract}
Introduction. Necrobiosis lipoidica (NL) is a granulomatous skin disease of still only partially known pathogenesis. Microangiopathy is considered as one of the most important processes in NL, and vascular endothelial growth factor (VEGF) and endothelin-1 are strongly involved in it. Recent studies have demonstrated the beneficial therapeutic effect of tumor necrosis factor $\alpha$ (TNF- $\alpha$ ) inhibitors in treatment of recalcitrant cases of NL, which is due to the important role of TNF- $\alpha$ in development of inflammation and granulomas in the course of NL.
\end{abstract}

Objective. To assess the serum levels of VEGF, endothelin-1 and TNF- $\alpha$ in NL patients.

Material and methods. The study group consisted of 17 patients with NL (mean age $48.22 \pm 15.99$ years), 37 patients with diabetes mellitus (mean age $52.11 \pm 17.41$ years) and 23 healthy volunteers (mean age 44.13 \pm 9.33 years) as a control group. Serum concentrations of TNF- $\alpha$, VEGF and endothelin-1 were assessed in all patients with the ELISA test.

Results. The TNF- $\alpha$ concentration was statistically lower in the controls when compared to the NL patients and diabetic patients $(p<0.05$ for all comparisons). There were no differences in VEGF serum levels between all the examined groups ( $p>0.05$ for all comparisons). Endothelin- 1 serum values were under the tested values in most cases; however, statistically more frequently these values were found in the controls than in the NL group $(p<0.05)$.

Conclusions. The results of our study suggest that inflammation with enhanced synthesis of TNF- $\alpha$ in NL patients is the primary pathological effect, followed by local impairment of angiogenesis.

\section{STRESZCZENIE}

Wprowadzenie. Obumieranie tłuszczowate (necrobiosis lipoidica - NL) jest chorobą ziarniniakową o nie do końca poznanej patogenezie. Niektórzy autorzy sugerują, że u podłoża choroby leży mikroangiopatia, w której rozwoju istotny udział przypisuje się czynnikowi wzrostu śródbłonka naczyniowego (ang. vascular endothelial growth factor VEGF) i endotelinie 1. Nowe dane z piśmiennictwa wskazują na korzystny efekt terapeutyczny inhibitorów czynnika martwicy nowotworów (tumor necrosis factor $\alpha-\mathrm{TNF}-\alpha$ ) w leczeniu opornych postaci NL, 
co prawdopodobnie wynika z udziału tej cytokiny w rozwoju zapalenia i tworzeniu ziarniniaków w przebiegu NL.

Cel pracy. Ustalenie stężenia VEGF, endoteliny 1 i TNF- $\alpha$ w surowicy chorych na NL.

Materiał i metody: Grupa badawcza składała się z 17 chorych na NL (średni wiek 48,22 $\pm 15,99$ roku), 37 chorych na cukrzycę (średni wiek $52,11 \pm 17,41$ roku) i 23 zdrowych wolontariuszy (średni wiek 44,13 $\pm 9,33$ roku) - grupa kontrolna. Stężenie wybranych białek określano metodą ELISA.

Wyniki. Średnie stężenie TNF- $\alpha$ było istotnie mniejsze w grupie kontrolnej $\mathrm{w}$ porównaniu z pacjentami z NL oraz chorymi na cukrzycę ( $p<0,05$ dla wszystkich porównań). Nie stwierdzono istotnych statystycznie różnic w stężeniu VEGF pomiędzy badanymi grupami ( $p>0,05$ dla wszystkich porównań). Stężenie endoteliny było poniżej wartości wykrywanych u większości badanych osób, jednak statystycznie istotnie częściej parametr ten był oznaczany w grupie kontrolnej niż u chorych na NL $(p<0,05)$.

Wnioski. Uzyskane wyniki mogą świadczyć, że stan zapalny przebiegający ze zwiększonym stężeniem TNF- $\alpha$ jest zjawiskiem zaangażowanym w rozwój NL, wyprzedzającym upośledzenie miejscowej angiogenezy.

\section{INTRODUCTION}

Necrobiosis lipoidica (NL) is a granulomatous skin disease of still unknown pathogenesis which usually appears in middle-aged women [1]. The NL more frequently is observed in diabetic patients, but it also may be accompanied by sarcoidosis, connective tissue diseases or inflammatory bowel diseases [2-4]. The NL association with diabetes mellitus is still controversial. Although up to $75 \%$ of patients with NL suffer from diabetes mellitus (DM), only $0.3-1 \%$ of diabetic patients present skin lesions of NL [5]. In the literature there are scarce data on the pathogenesis of necrobiosis lipoidica. Microangiopathy is considered as one of the most important phenomena in NL. Vascular endothelial growth factor (VEGF) is one of the most important factors involved in the initial process of angiogenesis [6, 7]. Effector cells for VEGF are endothelial cells. The VEGF is a mitogenic factor for these cells and promotes their proliferation. Their excessive proliferation is one of the phenomena involved in microangiopathy. Endothelial dysfunction is also due to increased production of the vasoconstrictor and pro-inflammatory peptide, i.e. endothelin-1. Some authors also suggest immunological disturbances leading to deposits of immunoglobulins in skin vessels and disturbances in platelet aggregation [8-12]. Recent literature data show that tumor necrosis factor $\alpha$ (TNF- $\alpha$ ) inhibitors such as adalimumab, infliximab or etanercept are beneficial in treatment of recalcitrant cases of necrobiosis lipoidica, which probably results from the fact that TNF- $\alpha$ plays an important role in development of inflammation and granulomas in the course of NL [13-16].

\section{OBJECTIVE}

The observations and suggestions of disturbed angiogenesis leading to microangiopathy in the course of NL were the reason why we decided to assess serum level of VEGF, endothelin and TNF- $\alpha$ in NL patients.

\section{MATERIAL AND METHODS}

The study group consisted of 17 patients with NL (13 women, 4 men, mean age $48.22 \pm 15.99$ years), 37 patients with diabetes mellitus (10 women, 27 men, mean age $52.11 \pm 17.41)$ and 23 healthy volunteers (10 women, 13 men, mean age $44.13 \pm 9.33$ years) who served as the control group. Four patients with NL suffered additionally from DM type II.

Serum samples obtained from all subjects were stored at a temperature of $-25^{\circ} \mathrm{C}$ until further analysis.

Serum concentrations of TNF- $\alpha$, VEGF and endothelin-1 were examined with the ELISA test according to the manufacturer's procedure. For TNF- $\alpha$ and VEGF we used assays obtained from R\&D Systems Quantikine (Minneapolis, USA), and for endothelin-1 assay from IBL International GmbH (Hamburg, Germany). 
Table I. Serum concentration of TNF- $\alpha$ and VEGF

\begin{tabular}{|c|c|c|c|c|c|c|c|}
\hline Parameter & Group & $N$ & $\begin{array}{c}\text { Mean } \\
\text { concentration } \\
{[\mathrm{pg} / \mathrm{ml}]}\end{array}$ & SD & Median & $\begin{array}{c}\text { Min. } \\
{[\mathrm{pg} / \mathrm{ml}]}\end{array}$ & $\begin{array}{c}\text { Max. } \\
{[\mathrm{pg} / \mathrm{ml}]}\end{array}$ \\
\hline \multirow{3}{*}{ VEGF } & Controls & 23 & 241.451 & 122.355 & 265.800 & 50.360 & 463.830 \\
\hline & $\mathrm{NL}$ & 17 & 286.533 & 119.136 & 269.927 & 98.875 & 555.524 \\
\hline & $\begin{array}{l}\text { Diabetic } \\
\text { patients }\end{array}$ & 38 & 294.697 & 202.422 & 282.885 & |3.84| & 794.584 \\
\hline \multirow{3}{*}{ TNF } & Controls & 23 & 0.580 & 0.833 & 0.000 & 0.000 & 2.490 \\
\hline & $\mathrm{NL}$ & 17 & $1.42 \mid$ & 1.004 & 1.525 & 0.000 & 3.060 \\
\hline & $\begin{array}{l}\text { Diabetic } \\
\text { patients }\end{array}$ & 38 & 1.998 & 2.368 & 1.125 & 0.000 & 9.570 \\
\hline
\end{tabular}

\section{Statistical analysis}

For statistical analysis the Mann-Whitney test, $\chi^{2}$ test with Yates' correlation and Spearman correlation were used. Statistical significance was found when $p<0.05$.

\section{RESULTS}

In the NL group mean serum concentration of TNF- $\alpha$ was 1.421 pg/ml (min. 0.001, max. $3.060 \mathrm{pg} /$ $\mathrm{ml}$ ) and of VEGF $286.533 \mathrm{pg} / \mathrm{ml}$ (min. $98.875 \mathrm{pg} / \mathrm{ml}$, max. $555.524 \mathrm{pg} / \mathrm{ml}$ ). Maximal concentration of endothelin- 1 in these patients was $0.804 \mathrm{fmol} / \mathrm{ml}$, although in most patients (16/17) its concentration was under the examined values.

In diabetic patients mean serum concentration of TNF- $\alpha$ was 1.998 pg/ml (min. 0.001, max. 9.570 pg/ $\mathrm{ml}$ ) and of VEGF $294.697 \mathrm{pg} / \mathrm{ml}(\mathrm{min} .13 .841 \mathrm{pg} / \mathrm{ml}$, max. $794.584 \mathrm{pg} / \mathrm{ml}$ ). Maximal serum concentration of endothelin-1 was $10.201 \mathrm{fmol} / \mathrm{ml}$, and in most examined patients $(31 / 38)$ its values were under the diagnostic level.
In the control group mean serum concentration of TNF- $\alpha$ was $0.580 \mathrm{pg} / \mathrm{ml}$ (min. 0.000, max. $2.490 \mathrm{pg} /$ $\mathrm{ml}$ ) and of VEGF $241.451 \mathrm{pg} / \mathrm{ml}(\mathrm{min} .50 .360 \mathrm{pg} / \mathrm{ml}$, max. $463.830 \mathrm{pg} / \mathrm{ml}$ ). Maximal serum concentration of endothelin-1 was $0.964 \mathrm{fmol} / \mathrm{ml}$, and in 11 out of examined patients its values were not diagnostic. Detailed values of serum concentrations of TNF- $\alpha$ and VEGF are shown in Table I.

Analyzing VEGF serum concentration we found no differences between the examined groups, i.e. either between NL patients and controls, or between diabetic patients and controls, or between NL patients and diabetic ones $(p>0.05$ for all comparisons).

Significant differences were found in mean serum concentration of TNF- $\alpha$ between the controls and other examined groups. The TNF- $\alpha$ concentration in the controls was statistically lower when compared to the NL patients and diabetic patients $(p<0.05$ for all comparisons). There were no significant differences in TNF- $\alpha$ serum values between NL and diabetic groups $(p>0.05)$ (Table II).

Table II. Comparisons of TNF- $\alpha$ and VEGF concentrations

\begin{tabular}{|c|c|c|c|c|c|c|c|}
\hline \multirow[t]{2}{*}{ Group } & \multirow[t]{2}{*}{$N$} & \multicolumn{3}{|c|}{ VEGF } & \multicolumn{3}{|c|}{ TNF } \\
\hline & & $\begin{array}{c}\text { Statistical } \\
\text { power }\end{array}$ & Likelihood & $\begin{array}{c}\text { Significance } \\
(p)\end{array}$ & $\begin{array}{c}\text { Statistical } \\
\text { power }\end{array}$ & Likelihood & Significance \\
\hline NL & 17 & \multirow{2}{*}{0.237} & \multirow{2}{*}{0.813} & \multirow{2}{*}{$>0.05$} & \multirow{2}{*}{-0.105} & \multirow{2}{*}{0.916} & \multirow{2}{*}{$>0.05$} \\
\hline DM & 38 & & & & & & \\
\hline NL & 17 & \multirow[b]{2}{*}{-1.064} & \multirow[b]{2}{*}{0.287} & \multirow[b]{2}{*}{$>0.05$} & \multirow[b]{2}{*}{-2.456} & \multirow[b]{2}{*}{0.014} & \multirow[b]{2}{*}{$<0.05$} \\
\hline Controls & 23 & & & & & & \\
\hline DM & 38 & \multirow[b]{2}{*}{-0.692} & \multirow[b]{2}{*}{0.489} & \multirow[b]{2}{*}{$>0.05$} & \multirow[b]{2}{*}{-2.656} & \multirow[b]{2}{*}{0.008} & \multirow[b]{2}{*}{$<0.05$} \\
\hline Controls & 23 & & & & & & \\
\hline
\end{tabular}




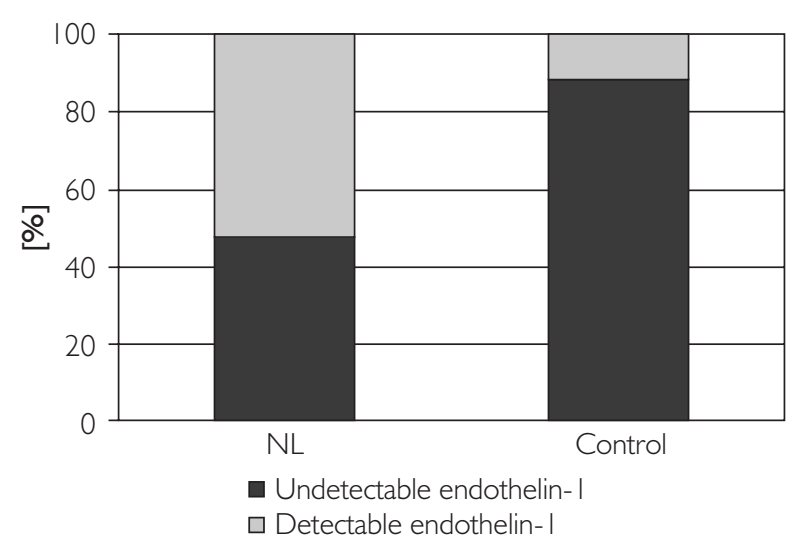

Figure I. Percentage of undetectable and detectable endothelin- I concentration in NL patients and controls

As endothelin-1 serum values were undetectable in most cases it was impossible to perform statistical analysis. However, we found significant differences in frequency of detectable endothelin 1 values between the NL group and controls. Statistically more frequently these values were found in the controls than in the NL group $(p<0.05)$ (Fig. 1.).

\section{DISCUSSION}

Necrobiosis lipoidica is a rare granulomatous skin disease of unknown etiology. In some cases it coexists with diabetes mellitus. In the available literature there are only scarce data on its pathogenesis. According to our knowledge there are no data on the serum levels of proinflammatory cytokines and factors involved in angiogenesis in patients with NL. Thus, observations made in our study are original. The TNF- $\alpha$ increases both proliferation and apoptosis in multiple cells and in this way it regulates their number [17]. This protein plays many important roles in our organism and is involved in the development of various diseases, including psoriasis, psoriatic arthritis, rheumatoid arthritis, Crohn's disease and diabetes mellitus type II [18]. Beneficial effects of TNF- $\alpha$ inhibitors were observed in most of these diseases, which confirms its crucial role in their pathogenesis [19].

We decided to assess TNF- $\alpha$ serum concentration in NL patients due to recent literature data indicating high effectiveness of TNF- $\alpha$ inhibitors (adalimumab, etanercept or infliximab) in NL patients. The authors of these publications suggest that it may result from an important role of TNF- $\alpha$ in generation of granulomas and pathogenesis of NL [13-16].

Literature data unequivocally prove the role of increased serum levels of TNF- $\alpha$ and inflammation in the development of diabetes mellitus [20]. In our study we revealed that concentration of this protein was significantly higher in NL and diabetic patients when compared to the controls, but we found no differences between the two examined patient groups. We should highlight that in the available literature there are no papers on TNF- $\alpha$ concentrations in NL, so our observation is the first one; however, because of the relatively small group of patients it requires further investigations.

As microangiopathy and disturbances in angiogenesis are considered as processes involved in NL [21], we also decided to examine serum concentrations of VEGF and endothelin-1 in the patients with this disease. In NL patients the VEGF serum level did not significantly differ when compared to the controls and diabetic patients. These results may indicate that an imbalance in angiogenesis in the course of NL takes place only locally and it has no systemic effect which is observed in the patients with malignancies or rheumatoid arthritis. In the literature there are many papers reporting increased levels of VEGF in diabetic patients, especially with retinopathy [22]. Our negative observations may result from the fact that all our diabetic patients were under close diabetic control, and the retinopathy that occurred in 12 of them was in very early stages. Endothelin-1 serum level was not investigated in NL patients. The results of the studies in the group of diabetic patients with controlled disease revealed that its level was comparable to the control group and our results are in line with this observation. According to Ugurlu et al. [23] endothelin serum concentration cannot be used to assess local imbalance of angiogenesis.

\section{CONCLUSIONS}

Based on the obtained results we may assume that inflammation with enhanced synthesis of TNF- $\alpha$ in NL patients is the primary event in pathogenesis of the disease, with subsequent impairment of angiogenesis.

\section{ACKNOWLEDGMENTS}

The study was supported by Medical University Research Project number 503/1-152-01/503-01.

\section{References}

1. Verrotti A., Chiarelli F., Amerio P., Morgese G.: Necrobiosis lipoidica diabeticorum in children and adolescents: a clue for underlying renal and retinal disease. Pediatr Dermatol 1995, 12, 220-223.

2. Mendoza V., Vahid B., Kozic H., Weibel S.: Clinical and pathologic manifestations of necrobiosis lipoidica-like skin involvement in sarcoidosis. Joint Bone Spine 2007, 74, 647649.

3. Magro C.M., Crowson A.N., Regauer S.: Granuloma annulare and necrobiosis lipoidica tissue reactions as a manifestation of systemic disease. Hum Pathol 1996, 27, 50-56. 
4. Jabbour S.A.: Cutaneous manifestations of endocrine disorders: a guide for dermatologists. Am J Clin Dermatol 2003, 4, 315-331.

5. Haralambous S., Blackwell C., Mappouras D.G., Weir D.M., Kemmett D., Lymberi P.: Increased natural autoantibody activity to cytoskeleton proteins in sera from patients with necrobiosis lipoidica, with or without insulin-dependent diabetes mellitus. Autoimmunity 1995, 20, 267-275.

6. Tischer E., Gospodarowicz D., Mitchell R., Silva M. Schilling J., Lau K., et al.: Vascular endothelial growth factor: a new member of the platelet-derived growth factor gene family. Biochem Biophys Res Commun 1989, 165, 1198-1206.

7. Mizia-Malarz A., Sobol G., Woś H.: Angiogeneza w przewlekłych schorzeniach zapalnych i nowotworowych. Pol Merkur Lek 2008, 24, 185-189.

8. Muller S.A., Winkelmann R.K.: Necrobiosis lipoidica diabetoricum histopathologic study of 98 cases. Arch Dermatol 1966, 94, 1-10.

9. Eldor A., Diaz E.G., Naparstek E.: Treatment of diabetic necrobiosis with aspirin and dipyridamole. N Engl J Med $1978,298,1033$

10. Ullman S., Dahl M.V.: Necrobiosis lipoidica: an immunofluorescence study. Arch Dermatol 1977, 113, 1671.

11. Peyrí J., Moreno A., Marcoval J.: Necrobiosis lipoidica. Semin Cutan Med Surg 2007, 26, 87-89.

12. Lowitt M.H., Dover J.S.: Necrobiosis lipoidica. J Am Acad Dermatol 1991, 25, 735-748

13. Suárez-Amor O., Pérez-Bustillo A., Ruiz-González I., Rodriguez-Prieto M.A.: Necrobiosis lipoidica therapy with biologicals: an ulcerated case responding to etanercept and a review of the literature. Dermatology 2010, 221, 117-121.

Otrzymano: $\quad 4$ IV 2014 r.

Zaakceptowano: 12 V 2014 r.
14. Leiser L., Korber A., Dissemond J.: Successful treatment of a patient with ulcerated necrobiosis lipoidica non diabeticorum with adalimumab Hautarzt 2013, 64, 509-511.

15. Barde C., Laffitte E., Campanelli A., Saurat J.H., Thielen A.M.: Intralesional infliximab in noninfectious cutaneous granulomas: three cases of necrobiosis lipoidica. Dermatology 2011, 222, 212-216.

16. Hu S.W., Bevona C., Winterfield L., Qureshi A.A., Li V.W.: Treatment of refractory ulcerative necrobiosis lipoidica diabeticorum with infliximab: report of a case. Arch Dermatol 2009, 145, 437-439.

17. Groves J., Wang Z., Newman W.H.: Two distinct phenotypes of rat vascular smooth muscle cells: growth rate and production of tumor necrosis factor-alpha. Am Surg 2005, 71, 546-551.

18. Lubecka-Macura A., Kohut M.: Nadrodzina TNF - mechanizmy działania, funkcje biologiczne i możliwości terapeutyczne. Prz Gastroenterol 2010, 5, 303-309.

19. Beyeart R., Fiers W.: Tumor necrosis factor and lymphotoxin cytokines. Akademic Press 1998, 4, 335-360.

20. Calle M.C., Fernandez M.L.: Inflammation and type 2 diabetes. Diabetes Metab 2012, 38, 183-191.

21. Ferrara N., Davis-Smyth T.: The biology of vascular endothelial growth factor. Endocr Rev 1997, 18, 4-25.

22. Marek N., Myśliwiec M., Raczyńska K., Zorena K., Myśliwska J., Trzonkowski P.: Increased spontaneous production of VEGF by CD4+ T cells in type 1 diabetes. Clin Immunol 2010, 137, 261-270.

23. Uğurlu N., Gerceker S., Yülek F., Ugurlu B., Sarı C., Baran P., et al.: The levels of the circulating cellular adhesion molecules ICAM-1, VCAM-1 and endothelin-1 and the flow-mediated vasodilatation values in patients with type 1 diabetes mellitus with early-stage diabetic retinopathy. Intern Med 2013, 52, 2173-2178. 